\title{
A Comparative Study of the Propensity of Whistle-Blowing: Empirical Evidence from China, Taiwan, and the United States
}

Dr. Dennis B.K. Hwang, Ph.D., CPA, CMA

Bloomsburg University of Pennsylvania, U.S.A

Dr. Yan Chen, Ph.D., CPA

Dongbei University of Finance and Economics, China

Dr. A. Blair Staley, D.B.A., CPA, CMA, CIA (Corresponding Author)

Bloomsburg University of Pennsylvania, U.S.A

Department of Accounting, College of Business

400 E. Second Street

Bloomsburg, PA 17815

E-Mail: astaley@bloomu.edu

Dr. Yafang Tsai, Ph. D.

Department of Health Policy and Management, Chung Shan Medical University, Taiwan

Chin-Ling Chu, Ph.D. Student

Tatung Institute of Commerce and Technology; Feng Chia University

Received: December 16, 2013 Accepted: December 28, 2013 DOI: 10.5296/ijafr.v3i2.4723

\begin{abstract}
This paper explores cultural factors that influence the propensity to blow-the-whistle in China, Taiwan, and the U.S. Statistical analysis of self-developed questionnaires reveals that: a) Americans have a greater disposition to engage in whistle-blowing than Chinese and
\end{abstract}


Taiwanese; b) the intention of Chinese and Taiwanese to whistle-blow is influenced to a greater degree by the dollar amounts involved and also by the impact of illegal, immoral or illegitimate practices on companies and societies than that of the Americans; c) Guanxi (personal relationships or networks) has a greater effect on the propensity to whistle-blow for Chinese and Taiwanese than for Americans. Auditors and managers need to be aware that employees in different cultures respond differently to factors that influence whistle-blowing. The results of this study will help auditors and managers better assess risk and the effectiveness of internal controls and ethical standards.

Keywords: whistle-blowing, cultural factors, Guanxi, internal controls, ethical standards

\section{Introduction}

Whistle-blowing is "the disclosure by members of an organization (former or current) of illegal, immoral, or illegitimate practices under the control of their employers, to persons or organizations that may be able to effect action" (Near \& Miceli, 1995, p. 4; see also Brody et al., 1999). Whistle-blowing is an important component of accounting and internal controls, and a critical way to prevent and deter fraud, waste, and abuse (Hooks et. al., 1994). However, while proponents who support whistle-blowing praise whistle-blowers as civic heroes, those who oppose whistle-blowing condemn them as "finks" (Duska, 2012). Most opponents believe that employees should have a prima facie duty of loyalty to their companies and not blow the whistle on colleagues' wrongdoings. Nevertheless, Duska (2012) denies the existence of such a duty because companies are not proper objects of loyalty. This study identifies the cultural factors that have an impact on the intention to whistle-blow.

Whistle-blowing and internal controls, which are very important to business ethics as well as economic stability, were emphasized in the report of Committee of Sponsoring Organizations of the Treadway Commission in the U.S. (COSO, 1992) and also in the Sarbanes-Oxley Act (2002). Moreover, the Association of Fraud Examiner's Fraud Examiners Manual (2005) stresses the importance of whistle-blowing in preventing and detecting fraud. The Chartered Institute of Public Finance and Accountancy in the U.K., the Middleton Report of the Australian Society of Certified Practicing Accountants, and the Institute of Chartered Accountants in Australia also link whistle-blowing and internal controls (Patel, 2003). This paper further explores the propensity in various cultures to blow the whistle. It compares the factors that encourage U.S. individuals (interchangeably referred to as Americans in this paper for ease of reading) to blow the whistle with the factors that encourage the Chinese in Taiwan and China to blow the whistle as well as those that discourage those same workers from whistle-blowing.

\section{The impacts of cultural factors and proposed propositions}

Although a critical component of internal control, whistle-blowing is affected by culture (Brody et al., 1999; Patel, 2003; Su, 2006; Keenan, 2007; Park et. al., 2007). In general, based primarily on the work of Hofstede and his colleagues (Hofstede, 1980, 1991; Hofstede 
\& Bond 1988), researchers theorize that individuals in individualistic and egalitarian cultures like the U.S. have a greater propensity to whistle-blow and would be more accepting of whistle-blowing than those in collective, hierarchical cultures like Chinese or Confucian cultures (see, e.g., Brody, et al., 1999; Patel, 2003; Su, 2006; Keenan, 2007; Park et. al., 2007). For example, Patel (2003) theorized and found that Australian accountants (as a proxy for Anglo-American countries, including the U.S.) are more likely to whistle-blow and are more accepting of whistle-blowing than Indian and Chinese-Malayan accountants, proxies for Asian-Indian and Confucian cultures. Keenan (2007) theorized and found that "Chinese managers are less likely to blow the whistle than their American counterparts" (p. 92).

Both China and Taiwan are deeply rooted in the Chinese culture, traditions, and Confucianism ( $\mathrm{Lu}$ et al., 2003). They share the same basic written characters in their written languages (except that some of the traditional characters have been simplified in China), dialects, literature, food, religions, common spoken language (Mandarin), and traditional holidays. Education is highly emphasized and both education and elders are greatly respected. But China and Taiwan have been governed by two different governments with diverse political and economic systems since their separation in 1949 when Chairman Mao defeated Chiang Kai-shek (Lu et al., 2003; Hwang et al. 2008). Perhaps because of its American and other western influences, Taiwan is more democratic, capitalistic, transparent and freer in many aspects. These two Chinese societies are treated as two different sub-cultural regions in this study because of their diverse political, social, and economic characteristics. We thus want this study to explore whether these differences would become salient contributors to the whistle-blowing behavior in China and Taiwan.

Specifically, whistle-blowing researchers point to Hofstede's (1980, 1991; Hofstede \& Bond, 1988) five dimensions of national culture - individualism, power distance, uncertainty avoidance, masculinity and long-term orientation-in theorizing why potential whistle-blowers in the U.S. may behave differently from potential whistle-blowers in Taiwan and China. Because of their widespread use in accounting research, this paper omits the detailed descriptions of each of these five dimensions (Chow et al., 2001). Rather, this paper briefly discusses the dimensions which researchers believe may affect propensity to whistle-blow among those in the United States, Chinese living in China (referred to as Chinese hereafter), and the Chinese living in Taiwan (as Taiwanese for convenience hereafter). Many researchers, such as Brody et al.(1999), Chow et al. (2001), and Tsui \& Windsor (2001), have focused on the effects of Hofstede's individualism and power distance dimensions on accounting and auditing.

A higher score for individualism refers to the cultural practice in which a member of a society focuses more on pursuing and protecting individual interest. A lower score for individualism refers to collectivism, the cultural practice wherein members of a group protect each other. A higher score on power difference refers to the cultural practice of following the chain of command or accepting more readily leadership directives or actions. As shown in Table 1, the U.S. national culture differs from that of Taiwan and China on these measures. The U.S. national culture is much more individualistic and egalitarian, much less accepting of 
power distances and therefore much more independent. Researchers believe these differences impact individuals' (including accountants') propensity to whistle-blow. Notably the scores of individualism for China and Taiwan are very close, while their scores on the other four dimensions are relatively different, reflecting the fact that China and Taiwan share common traditions and cultures and but have some significant differences.

Insert Table 1 about here

In regard to individualism, collectivist Taiwanese and Chinese may be less likely to blow the whistle to avoid an uncomfortable work situation possibly arising from exposing the group by disclosing its illegal, immoral or illegitimate practices (Brody et al., 1999). That is, to protect the group as a whole and to protect their place in the group, the collectivist individuals in Taiwan and China may be less likely to blow the whistle. The same concern may not be present for people in individualistic cultures, who do not as a rule look for the group for protection. Indeed, individuals in individualistic cultures such as the U.S. may be encouraged to blow the whistle to prevent the illegal, immoral or illegitimate practice from affecting themselves. That is, by blowing the whistle, the persons in an individualistic culture a) ensure that they themselves would not be blamed for those practices, b) reduce the possible negative effect of the practice on themselves and others, whether those effects be social in terms of an uncomfortable working conditions or economic in terms of lower net income or worse effects on a social group, and c) may be viewed as heroic in exposing the illegal, immoral or illegitimate practice.

Furthermore, whistle-blowing can be largely divided into external and internal categories, based on whether the wrongdoing is reported through internal channels or to outsides (Park et al., 2005). Triandis and Gelfand (1998) argue that both individualism and collectivism might be horizontal (emphasizing equality) or vertical (emphasizing hierarchy) (p. 118). They also suggest that each type of cultural attitude might affect whistleblowing intentions in both direction and degree. Park et al. (2005) find that Confucian ethics and collectivism appeared to have significant effects on whistleblowing, but were not consistent in their direction and degree as has been commonly thought. This study focuses on the overall effect of a cultural attribute on a respondent's willingness to blow the whistle; therefore, this research does not distinguish between internal or external whistleblowing, nor does it identify whether the individualism and collectivism is horizontal or vertical.

Power difference is likely to have a similar effect on the propensity to blow the whistle. Americans may be more willing to blow the whistle as they would view themselves as having equal rights vis-à-vis the persons involved in the illegal, immoral or illegitimate practices (Brody, et al., 1999; Patel, 2003; Su, 2006; Keenan, 2007; Park et. al., 2007). They would also feel more secure and therefore would be less cautious in blowing the whistle. By contrast, Taiwanese and Chinese may be less likely to blow to whistle as they would be more likely to follow the lead of the organization in tolerating the illegal, immoral or illegitimate 
practice (Keenan, 2007).

The following proposition flows from the literature discussed infra:

P1: Americans will have a greater disposition to engage in whistle-blowing than Chinese and Taiwanese.

While collectivist cultures may in general be less likely to blow the whistle (Keenan, 2007; Patel, 2003), Keenan (2007) theorizes and finds that such cultures may in some respects be more critical of illegal, immoral, or illegitimate practices if such practices, even if immaterial, represent potential threats to the collective. The following proposition follows from these studies and also the studies discussed previously:

P2: The intention of Chinese and Taiwanese to whistle-blow will be influenced to a greater degree by the dollar amounts involved and also by the impact of illegal, immoral or illegitimate practices on companies/societies than that of Americans.

Another complicating cultural factor in regard to whistle-blowing, especially in Confucian societies is guanxi. Guanxi-or the informal network of business/social associations based on personal relationships that are based on trust and mutual benefit-operates on the premise that people who share a guanxi relationship are bound to each other by an unspoken code of reciprocity and equity (Luo, 1997). Individuals must fulfill their responsibilities in the guanxi circle, and those who fail to fulfill them lose prestige within their guanxi circle, including the loss of face and loss of trust by fellow members of the circle (Hwang \& Staley, 2005). As whistle-blowing would not be in accord with guanxi, it is likely that guanxi would reduce the propensity to blow the whistle (Au \& Wong, 2000). Hwang et al. (2009) suggest that "professional ethical codes should provide guidance on the practice of guanxi in a Confucian society and that special emphasis or training in interpreting those codes may be required" (p. 1). The following proposition emerges from the studies discussed previously and the literature on guanxi.

P3: Guanxi will have a greater negative effect on the propensity to whistle-blow for Chinese and Taiwanese than for Americans.

Because of the importance of whistle-blowing to internal controls and because propensity to whistle-blowing is affected by culture, U.S. companies doing business in Taiwan or China and in Confucian cultures generally need to understand what factors might encourage whistle-blowing, and what factors might discourage whistle-blowing. Similarly, companies from Taiwan or China and companies from Confucian cultures generally doing business in the U.S. need to understand what items might encourage or discourage whistle-blowing.

\section{Method}

\subsection{Questionnaire Design and Sample}

A survey questionnaire (see Appendix) was designed to test the impact of culture on whistle-blowing intentions. A total of twenty-four questions were created and classified into five sections. The first section (Section A) contains questions asking whether and to what 


\section{MInstitute Macrothink $_{\text {Int }}^{\text {Intion }}$}

International Journal of Accounting and Financial Reporting ISSN 2162-3082

degree a respondent (a potential whistle-blower) agrees with factors that may encourage whistle-blowing, such as social justice, professional ethics, sense of morality, monetary rewards, promotions, peer encouragement and job protection. The second section (Section B) contains questions asking whether and to what degree a respondent agrees with factors that may discourage whistle-blowing, such as a company's strong internal control system, media attention, retaliation, a sense of betrayal, and Confucius' teaching. The third section (Section C) consists of questions that ask whether and to what degree a respondent agrees or disagrees that whistle-blowing intention may be affected by some related factors, such as the amount of money involved and the degree to which the breach threatens the company and society. The fourth section (Section D) is comprised of questions asking whether and to what degree a respondent agrees or disagrees with statements that personal relationships (guanxi in Confucian cultures) negatively affect the propensity to whistle-blow. Finally, the last section (Section E) of the questionnaire contains questions regarding the respondent's demographics, including age, gender, education, work experience and religious beliefs.

A 7-point Likert-type scale was anchored to each question in the first four sections of questions, where 1 indicated "strongly disagree" and 7 indicated "strongly agree." Respondents were asked to express their preferred value for each question.

The questions were derived from the whistle-blowing literature. For example, the question "I would not be a whistle-blower because my organization might retaliate against me" was derived following the review of analyses of whistle-blowing retaliation such as Beard's (2007). The questions on guanxi were derived from Hwang and Staley (2005).

The questions were jointly composed in English by a native English-speaking researcher and by a bi-lingual English/Chinese researcher. Each item was then translated to Chinese by a bi-lingual researcher, and carefully reviewed by native-Chinese speaking researchers. Both the English and Chinese language versions of the questionnaire thus captured the same concepts. The questionnaires were distributed and collected in Taiwan in 2008, in China during late 2009 and early 2010, and in the U.S. in 2011.

A total of 1,250 Chinese-language questionnaires were distributed to CPA firms, corporations, professional associations and universities via mail or personal delivery in Taiwan. A total of 485 questionnaires were returned, a response rate of $39 \%$. Four hundred and thirty-nine questionnaires, a response rate of $35 \%$, had all questions answered, which formed the usable sample.

A total of 1,450 Chinese-language questionnaires were distributed in China, of which 411 were usable, a response rate of $29 \%$. A total of 5,000 English-language questionnaires were mailed to randomly selected members of the general accounting category of the Institute of Management Accountants' (IMA) mailing list. Two hundred and forty-five usable surveys were received, a response rate of five percent. Because of the low response rate for the U.S./IMA questionnaires, an independent sample t-test comparison was performed comparing the first 30 responses received with the last 30 responses received. This analysis revealed no statistically significant differences in the responses for questions A1 through D1, for the gender of the respondent, or whether the respondent was a CPA. This provides some level 
of assurance against possible low response bias.

Insert Table 2 about here

\section{Results}

\subsection{Background of Respondents}

Table 2 shows background information of the respondents. Taking all respondents from these three countries as a whole, a majority of the respondents were not CPAs, were female, had 11 years or more of work experience, had between 13-16 years of education, were between 21-25 years old, and indicated they were agnostic or atheist. The majority of the Taiwanese respondents indicated they were Buddhists/Taoists/Confucians, while the majority of the Chinese respondents indicated they were agnostic or atheists. The majority of the American respondents were male, had more work experience (11 years and over), had more years of education (17 and over), were older in age (36 and above), and were mainly Christians. That the American respondents had greater work experience, were older, and had more years in education should help increase the reliability and comparability of the American data because the respondents with these characteristics should possess better understanding of Chinese cultures than those younger, less experienced, and less educated.

Insert Table 3 about here

\subsection{The Comparisons among China, Taiwan and the U.S.}

Table 3 shows the results of the mean of the Likert scores and the signification level for each question, using Chinese, Taiwanese and American respondents as the three subgroups for analysis. With a 7-point Likert scale, an average of 4 indicates the respondents are neutral on a question. Respondents agree more strongly when the mean is closer to 7 . Respondents agree less strongly when the mean is closer to 1 .

\subsection{Factors that may encourage whistle-blowing}

Section A questions inquire whether and to what degree a respondent agrees with factors that may encourage whistle-blowing. A general sense of morality receives the highest average (6.14 for U.S., 5.73 for China, and 5.19 for Taiwan) and therefore is the factor having the strongest agreement among recipients, followed by social justice and professional ethics (6.08 for U.S., 5.64 for China, and 4.99 for Taiwan), and the policies/laws on whistle-blowing (5.40 for U.S., 4.64 for China, and 4.42 for Taiwan). Furthermore, all of the means for the respondents in these three countries for these three factors were greater than four (the 


\section{Mll Macrothink}

International Journal of Accounting and Financial Reporting ISSN 2162-3082 2013, Vol. 3, No. 2

midpoint of the Likert scale). The U.S. has the highest scores throughout, followed by China and then Taiwan. In addition, all three cultures reveal significant differences in their means. This finding implies these three factors are all significant motivators to whistle blow in these three countries, yet each factor's propensity to whistle blow differs (U.S. as the highest, followed by China and Taiwan). The factor of legal job protection for whistle-blowers probably reflects a significant encouraging factor in the U.S. (4.26), but it becomes insignificant in China (3.74) and Taiwan (3.79). So far, all results reasonably reflect that Americans have higher respect and trust in social justice, ethics, morality, corporate policy, and laws and regulations than the Chinese and Taiwanese. Therefore, Proposition 1 is supported by our results that Americans will have a greater disposition to engage in whistle blowing than Chinese and Taiwanese.

The means of the encouraging factors of both peer encouragement and monetary award or promotion are less than four, the midpoint of the Likert scale, in all three countries. Thus, they are not significant motivators for whistle blowing.

\subsection{Factors that may discourage whistle-blowing}

Section B questions ask whether respondents agree that a particular factor would decrease their propensity to blow the whistle. "Attention from the media" was the only factor the respondents of all three countries agree would decrease their propensity to blow the whistle (4.67 for Taiwan, 4.41 for China, and 4.11 for U.S.). Taiwanese and Chinese respondents also indicate much agreement that the other two items - "retaliation from organization" and "retaliation from involved individuals"-would decrease their propensity to whistle-blow. Only the Taiwanese respondents indicate much agreement that if the country or firms have strong internal control and legal systems, they would have less willingness to whistle blow. The factors of "own religion," "own moral consciousness," and "Confucius teaching" reveal have no significant impacts on whistle-blowing in all three countries. In summary, out of eight questions in the category of discouraging factors for whistle blowing, Taiwan has five factors with significant impact (with a mean greater than four) on the intention of whistle blowing, China has three, and the U.S. has only one. These results imply that citizens with Anglo-American cultures are less discouraged by the possible negative impacts on them if they whistle blow on fraud, and the citizens under Confucianism are more discouraged by those factors and thus are more inclined not to whistle blow. Therefore, these results and their implications also support Proposition 1 that Americans will have a greater propensity to engage in whistle blowing than Chinese and Taiwanese.

\subsection{Impact of illegal, immoral or illegitimate practices on money and organizations}

The first question of section $\mathrm{C}$ seeks to determine whether the dollar amount of the illegal, immoral or legitimate practice affects intention to whistle-blow. The respondents of all three countries agree that the greater the monetary amount, the greater their intention to whistle-blow (with means 4.74 for China, 4.46 for Taiwan, and 4.36 for U.S.). The second question of section $\mathrm{C}$ seeks to determine whether the greater impact of the illegal, immoral or legitimate practice on the existence/interest of the company or the country would more greatly affect the intentions to whistle-blow. In this area, the respondents in China reveal a 


\section{Mll Macrothink}

International Journal of Accounting and Financial Reporting

ISSN 2162-3082

2013, Vol. 3, No. 2

mean of 5.99 and in Taiwan with a mean of 5.22, while the respondents in the U.S. with 5.25. These results confirm Proposition 2 that the intention to whistle-blow of the Chinese/Taiwanese (under Confucianism cultures) will be influenced to a greater degree by both the impact and money amounts of the fraud than in the U.S. (Anglo-American cultures).

\subsection{Impact of personal relationships (guanxi) on whistle-blowing}

Section D questions ask whether and to what degree a respondent agrees or disagrees that the establishment of business relationships through informal networks based on personal relationships, relationships based, in turn, on trust and mutual benefit, affects propensity to whistle-blow. In Confucian cultures, this relationship is known as guanxi. Most importantly, for this study, Chinese /Taiwanese respondents (4.87/4.72) indicate much agreement that "My personal relationship(s) in business based on trust and mutual benefit with the person or persons involved in the illegal, immoral or illegitimate practices in my organization would negatively affect my intention to whistle-blow," while on average U.S. respondents indicated less agreement with this statement (3.38). Therefore, our results confirm Proposition 3 that guanxi will have a greater negative effect on the propensity to whistle-blow for Chinese and Taiwanese than for Americans.

In summary, the results of the statistical analysis ( $t$-test) reveal that sixteen out of the total of seventeen questions on the questionnaires present significant differences in the responses among China, Taiwan, and the U.S. most likely due to their different cultures, and political/economic/social systems, and only one question's responses (peer encouragement) indicate that there are no significant differences among these three countries. To further explore significant differences in the responses in each pair of two countries, the results of the factor analysis for each pair are presented on Tables 4-6.

\subsection{Taiwanese vs. Chinese Analysis}

Table 4 shows the results of the $t$-test for the questions, using Taiwanese and Chinese respondents as the two subgroups. Out of the total of seventeen questions, the responses to eight questions reveal significant differences between these two subgroups. These eight questions are social justice and professional ethics, general sense of morality, monetary awards, strong internal control, stronger legal system, own religion, greater amounts in fraud-greater intention to whistle- blow, and greater impact of the fraud-greater intention to whistle-blow. As noted in the previous section, people living in Taiwan and mainland China share the same languages, religions, literature, culture, traditions, and Confucianism, but they have nurtured many differences in the ways of thinking and lives from the differences in their political, economic, legal, and social systems. This study indicates these differences have influenced the whistle-blowing intentions and behaviors in China and Taiwan.

Insert Table 4 about here 


\subsection{Chinese/Taiwanese vs. Americans Analysis}

Tables 5 and 6 present the results of the factor analysis, using the data of each pair of Taiwan-U.S. and China-U.S. Out of the total of seventeen questions, only the responses to two questions (peer encouragement and greater monetary amounts in fraud - greater intention to blow whistles) indicate no significant differences between the Taiwanese and Americans (see Table 5). Also, only the responses to two questions (peer encouragement and media attention) indicate no significant differences among the Chinese and Americans (see Table 6). These results imply that the differences in the cultures, moral/ethical senses, and legal/social systems in the East and West contribute to make the differences in the propensity of whistle-blowing in American and Confucianism regions.

Insert Tables 5 and 6 about here

\section{Discussion}

In general, the results of this study support all three of the propositions. More broadly, the results support the theory and research that cultural factors affect individuals' (including accountants') propensity to whistle-blow. Individuals in individualistic and egalitarian cultures appear to have a greater propensity to whistle-blow and appear to be more accepting of whistle-blowing than people in collective, hierarchical societies (Patel, 2003; Su, 2006; Keenan, 2007; Park et. al., 2007). However, individuals' propensity to whistle blow in collective, hierarchical societies appears to be influenced to a greater degree by the impact of the illegal, immoral, or illegitimate practices on their organizations than that in individualistic and egalitarian societies (Keenan, 2007). The results also indicate that the cultural factor guanxi, where people are bound to each other by an unspoken code of reciprocity and equity (Luo, 1997), negatively affects propensity to whistle-blow (Au \& Wong, 2000; Hwang et al., 2008; Hwang \& Staley, 2005).

Specifically, as discussed previously, respondents are in strongest agreement that a general sense of morality is the factor that most encourages whistle-blowing, followed by social justice and professional ethics and abiding by the policy of their organizations. Further, the means for these three factors that might encourage whistle-blowing were significantly greater for the U.S. respondents than those of the Taiwanese and Chinese respondents. These results may imply that Americans have internalized business-related aspects of morality, social justice and professional ethics, and the behavior of individuals in organizations to a greater degree than Taiwanese and Chinese respondents, perhaps due to the longer history of democracy and capitalism in the U.S. These results further suggest that firms operating in Taiwan and China may not be able to rely on their citizens' general sense of morality, professional ethics and perceptions of fairness, or the policy of their organization to 


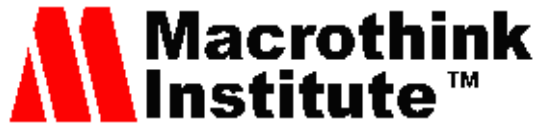

International Journal of Accounting and Financial Reporting ISSN 2162-3082 2013, Vol. 3, No. 2

encourage whistle-blowing to the extent they might in the U.S. In addition, the means for the factor of the whistle-blowing encouraged by monetary awards and promotion are all lower than four in all three countries (mean for China 3.09, Taiwan 3.50, and U.S. 2.71). This implies that monetary award and promotion do not effectively motivate whistle-blowing in these three countries. This finding of the apparent ineffectiveness of monetary rewards contrasts with the assumptions behind legislation (such as the U.S.'s False Claims Act) that provides monetary rewards to encourage whistle-blowing (Eaton \& Akers, 2007). The means for the factor of fear of media attention are larger than four in all three countries (China 4.41, Taiwan 4.67, and the U. S. 4.11). This is consistent with potential whistle-blowers' fear of victimization (see, generally, Lewis, 2007) and it suggests that firms operating in U.S. or Taiwan/China may wish to institute policies that would offer some degree of protection against media exposure for whistle-blowing (e.g., anonymous hotlines) if they wish to promote whistle-blowing. The results also imply that firms operating in media-intensive locations (New York, Beijing, and Taipei perhaps) need to have stronger internal controls to discourage and prevent frauds.

The factors of the fear of retaliation from the organization and involved individuals in China and Taiwan (all much higher than four) are significantly higher than those in the U.S. (all lower than four). This implies that the improvement in law or regulation (like the Sarbanes and Oxley Act in the U.S.) for encouraging and protecting whistle-blowing is more desirable and necessary in China and Taiwan than in the U.S.

Section D questions ask whether and to what degree a respondent agrees or disagrees that the business relationships through informal networks based on personal relationships (or guanxi) affects propensity to whistle-blow and other behaviors. The responses reveal that people in Confucian cultures generally believe that they are negatively affected by these relationships.

Most importantly, the Taiwanese/Chinese respondents (4.72/4.87) agree that "My personal relationship(s) in business based on trust and mutual benefit with the person or persons involved in the illegal, immoral or illegitimate practices in my organization would negatively affect my intention to whistle-blow," while U.S. respondents indicate little agreement with this statement (3.38). This statistically significant difference reinforces other studies showing that guanxi affects accounting in Confucian societies (Goodwin and Yeo, 2001; Hwang and Staley, 2005; Cooper et al., 2006; Hwang et al., 2008 and 2009). It also may mean that U.S. companies and U.S. auditors working in Confucian societies should be aware of the guanxi network in which the firm or clients operate and that they will need to have stronger internal controls and better practice of ethics with regard to transactions and reporting within the guanxi network to offset the reduced propensity to whistle-blow.

\subsection{Conclusion}

Demand for accountants in China is rapidly increasing (Tucker, 2008). Depending on employees to inform management of misdeeds, or whistle-blowing, plays a critically important part of accounting and internal controls. Culture, however, affects an employee's propensity to whistle-blow. Thus, firms hiring accountants should be aware of the differences in the propensity to whistle-blow between U.S. (and by extension, 


\section{MInstitute ${ }^{\text {Mech }}$}

International Journal of Accounting and Financial Reporting ISSN 2162-3082 2013, Vol. 3, No. 2

Anglo-American) accountants and Taiwanese/Chinese accountants. Firms operating in Confucian societies generally should be aware of the differences in the propensity to whistle-blow between U.S. and Taiwanese/Chinese accountants (and by extension, accountants from Confucian cultures). Similarly, firms from Confucian cultures operating in the U.S. (and by extension, Anglo-American countries) should be aware of differences in the propensity to whistle-blow.

This research paper highlights differences in the reactions of Americans and Taiwanese/Chinese to factors that may increase propensity to whistle-blow and to factors that may decrease whistle-blowing propensity - a key component of a program for internal controls. It also highlights differences in propensity to whistle-blow based on the impact of the illegal, immoral, or illegitimate practice on money and organizations. Finally, the research highlights differences in how personal relationships or guanxi affect propensity to whistle-blow. In this way, firms can adopt programs that strengthen the items that encourage whistle-blowing, and that counteract the items which discourage whistle-blowing. Firms can adopt stronger compensating controls to maintain effective internal controls where propensity to whistle-blow may be weakened. Stronger implementation of sound ethical standards, better practice of ethical conducts, and effective corporate governance are desired in all cultures, but are much more needed in Confucianistic societies to counteract the practice of "guanxi" and the fear of retaliation.

\section{References}

Association of Certified Fraud Examiners: 2005, '2005 Fraud examiner's manual', San Antonio, TX: Association of Certified Fraud Examiners, Inc.

Au, A. K. M., and D. Wong: 2000, 'The impact of Guanxi on the ethical decisoin-making of auditors - An exploratory study on Chinese CPAs in Hong Kong', Journal of Business Ethics 28 (1), 87-94.

Beard, D.: 2007, 'Retaliation: Unlawful, unethical, or just to be expected?', Strategic Finance 89(2), 32-36.

Brody, R., J. Coulter, and S. Lin: 1999, 'The effect of national culture on whistle-blowing perceptions', Teaching Business Ethics 3(4), 385-400.

Chow, C. W., T. Lindquist, and A. Wu: 2001, 'National Culture and Implementation of High-Stretch Performance Standards: An exploratory study', Behavioral Research in Accounting 13, 85-109.

Committee of Sponsoring Organizations of the Treadway Commission: 1992, Internal Control Integrated Framework (Coopers \& Lybrand).

Cooper, B. M., P. Leung, and G. Wong: 2006, 'The Asian Pacific literature review on internal auditing', Managerial Auditing Journal 21(8), 822-34.

Corvino, John: 2002, “Loyalty in Business?” Journal of Business Ethics 41:179-185.

Duska, Ronald: 2012, "Whistle-Blowing and Employee Loyalty", website: 
http://philosophia.uncg.edu/sites/default/files/PHI361metivier/readings/Duska-Whistle-Blowi ng.pdf

Eaton, T. V., and M. Akers: 2007, 'Whistleblowing and good governance: Policies for universities, government entities, and nonprofit organizations', The CPA Journal, retrieved December 16, 2008 from http://www.nysscpa.org/cpajournal/2007/607/essentials/p58.htm

Goodwin, J. and T. Yeo: 2001, 'Two factors affecting internal audit independence and objectivity: evidence from Singapore', International Journal of Auditing 5, 107-125.

Hofstede, G.: 1980, Culture's consequences, Beverly Hills, CA: Sage Publications.

Hofstede, G.: 1991, Cultures and organization: Software of the mind, New York: McGraw Hill.

Hofstede, G., and M. H. Bond: 1988, 'The Confucius connection: From cultural roots to economic growth', Organizational Dynamics 16 (4), 5-21.

Hooks, K. L., S. Kaplan, J. Schultz, and L. Ponemon: 1994, 'Enhancing communication to assist in fraud prevention and detection; Comment: Whistle-blowing as an internal control mechanism: Individual and organizational considerations', Auditing 13(2), 86-115.

Hwang, D. B. K., A. Staley, Y. Chen, and J. Lan: 2008, 'Confucian Culture and Whistle-Blowing by Professional Accountants: An Exploratory Study', Managerial Auditing Journal 23(5), 504-526. DOI 10.1108/ 02686900810875316.

Hwang, D. B. K., P. Golemon, Y. Chen, T. Wang, and W. Hung: 2009, 'Guanxi and business ethics in Confucian society today: An empirical case study in Taiwan', Journal of Business Ethics 89(2), 235-250.

Hwang, D. B. K. and A. Staley: 2005, 'An analysis of recent accounting and auditing failures in the United States on U.S. accounting and auditing in China', Managerial Auditing Journal 20 (3), 227-234.

Keenan, J. P.: 2007, 'Comparing Chinese and American managers on whistleblowing', Employee Responsibilities and Rights Journal 19(2), 85-94.

Lewis, D.: 2007, 'Personal and vicarious liability for the victimization of whistleblowers', Industrial Law Journal 36, 224-227.

Lu, L., C. Cooper, S. Kao, and Y. Zhou: 2003, 'Work Stress, Control Beliefs and Well-being in Greater China: An Exploratory of Subcultural Differences between the PRC and Taiwan', Journal of Managerial Psychology 18(6), 479-510.

Luo, Y.: 1997, 'Guanxi: principles, philosophies, and implications', Human Systems Management 16 (1), 43-51.

Near, J. and M. Miceli: 1995, 'Effective whistle-blowing', Academy of Management Review 20, 679-708.

Park, H, Rehg, M.T., and Lee, D: 2005, “The Influence of Confucian Ethics and Collectivism 


\section{N Macrothink}

International Journal of Accounting and Financial Reporting

ISSN 2162-3082 2013, Vol. 3, No. 2

on Whistleblowing Intention: A Study of South Korean Public Employees. Journal of Business Ethics, Vol. 58, 387-403.

Park, H., J. Blenkinsopp, M. Oktem, and U. Omurgonulsen: 2007, 'Cultural orientation and attitudes toward different forms of whistleblowing: A comparison of South Korea, Turkey, and the U.K. ', Journal of Business Ethics 82 (4), 929-939.

Patel, C.: 2003, 'Some cross-cultural evidence on whistle-blowing as an internal control mechanism', International Accounting Research 2, 69-96.

Su, S.: 2006, 'Cultural differences in determining the ethical perception and decision-making of future accounting professionals: A comparison between accounting students from Taiwan and the United States', Journal of American Academy of Business 9 (1), 147-158.

Triandis H. C. and Gelfand, M. J.:1998, "Converging Measurement of Horizontal and Vertical Individualism and Collectivism. Journal of personality and Social Psychology, 74(1), 118-128.

Tsui, J. and C. Windsor: 2001, 'Some cross-cultural evidence on ethical reasoning', Journal of Business Ethics 31(2), 143-150.

Tucker, S.: 2008, 'Accountants plan China recruiting drive', Financial Times, retrieved December 16, 2008 from: http://www.ft.com/cms/s/0/3835f956-cad4-11dd-87d7-000077b07658.html 
Appendix

WHISTLE BLOWING AND BUSINESS RELATIONSHIPS QUESTIONNAIRE FOR PROFESSIONALS (COPYRIGHT AUTHORS 2005.

This questionnaire is for professionals, and students studying to be professionals. It is composed of Sections A through $\mathrm{E}$. The instructions for each section are at the beginning of each section. Please respond to all items.

\section{Section A}

The following factors may encourage whistle-blowing -- the disclosure by organization members (former or current) of illegal, immoral or illegitimate practices under the control of their employers, to persons or organizations that may be able to effect action. Please indicate the impact of each factor on your whistle"strongly disaree" while 7 indicates "strongly agree."

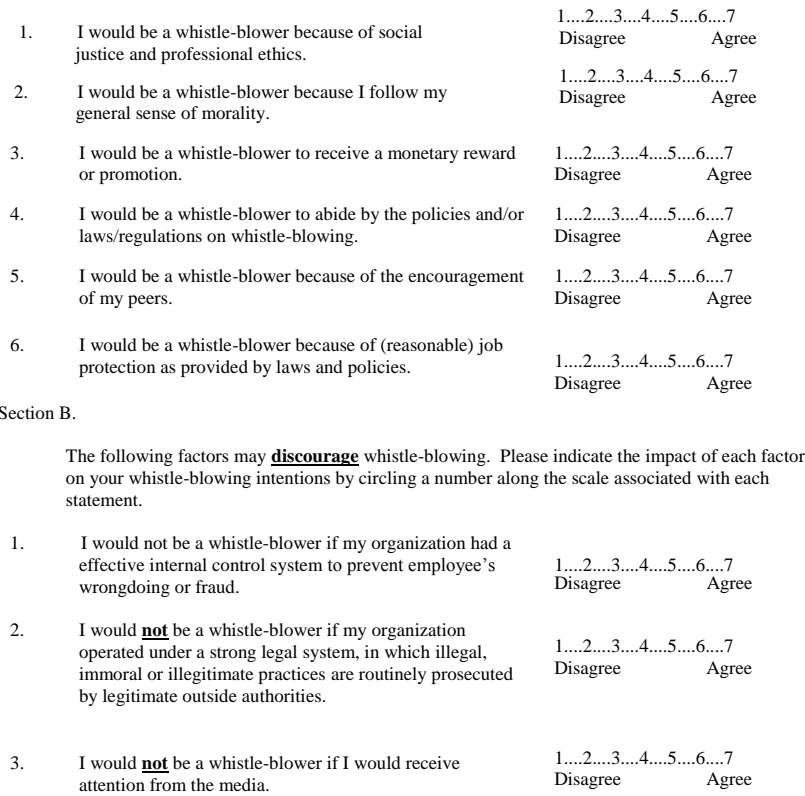




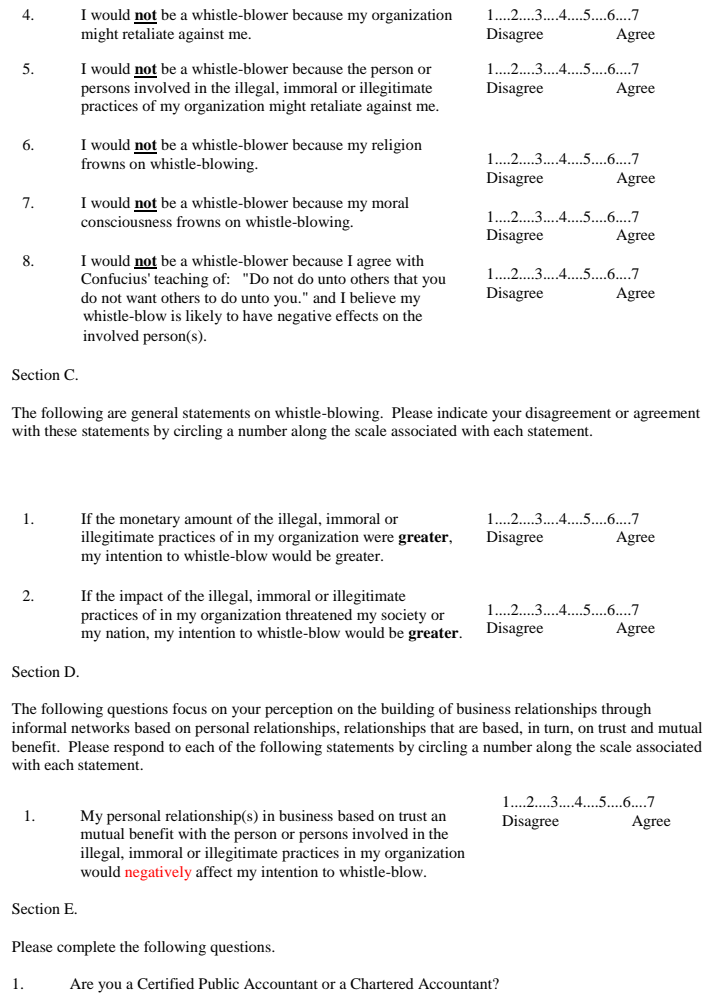




\section{Macrothink}

International Journal of Accounting and Financial Reporting

ISSN 2162-3082 2013, Vol. 3, No. 2

2. Are you a full time student?
a. $\quad$ Yes
b. No

3. What are the total years of education you received?

$\begin{array}{lllllllll}12 & 13 & 14 & 15 & 16 & 17 & 18 & 19 & 20\end{array}$

4. When did you first start work as a full time, paid professional?

$\overline{\text { Month }} \overline{\text { Year }}$

5. How old were you on your last birthday?

years

6. Are you --

a. Female (check if yes) b. Male (check if yes)

7. Are you (please check only one)--
a. Agnostic/Atheist (check if yes)
b. Buddhists/Taoist/Confucian (check if yes)
c. Christian/Catholic (check if yes)
d. Others (check if yes)

Please return the completed questionnaire in the postage-paid envelope. 


\section{Macrothink \\ International Journal of Accounting and Financial Reporting \\ ISSN 2162-3082 2013, Vol. 3, No. 2}

Table 1

\begin{tabular}{llllll} 
Hofstede's Culture Dimensions & 1 & 2 & 3 & 4 & 5 \\
\hline & Power & Individualism & Masculinity & Uncertainty & Long-term \\
& Distance & & & Avoidance & Orientation \\
U.S. & 40 & 91 & 62 & 46 & 29 \\
Taiwan & 58 & 17 & 45 & 69 & 87 \\
China & 80 & 20 & 66 & 30 & 118
\end{tabular}

Source: http://www.geert-hofstede.com/hofstede dimensions.php?culture1=95\&culture2=89, retrieved December 7, 2009. 
Table 2

\section{Background Information on}

Respondents

\begin{tabular}{|c|c|c|c|c|c|}
\hline & $\begin{array}{l}\text { China } \\
\text { (Number) }\end{array}$ & $\begin{array}{c}\text { Taiwan } \\
\text { (Number) }\end{array}$ & $\begin{array}{c}\text { U.S. } \\
\text { (Number) }\end{array}$ & $\begin{array}{l}\text { Total } \\
\text { (Number) }\end{array}$ & $\begin{array}{l}\text { Total } \\
\text { (Percent) }\end{array}$ \\
\hline \multicolumn{6}{|l|}{ CPA vs. Non-CPA } \\
\hline CPA & 59 & 32 & 106 & 197 & $18 \%$ \\
\hline Non-CPA & 352 & 407 & 139 & 898 & $82 \%$ \\
\hline \multicolumn{6}{|l|}{ Gender a/ } \\
\hline Female & 223 & 267 & 75 & 565 & $53 \%$ \\
\hline Male & 188 & 172 & 150 & 510 & $47 \%$ \\
\hline \multicolumn{6}{|l|}{ Work Experience b/ } \\
\hline 0 years & 207 & 126 & 11 & 344 & $32 \%$ \\
\hline $1-5$ years & 94 & 162 & 0 & 256 & $24 \%$ \\
\hline $6-10$ years & 62 & 61 & 19 & 123 & $12 \%$ \\
\hline 11 and Over & 102 & 90 & 157 & 349 & $33 \%$ \\
\hline \multicolumn{6}{|l|}{ Education } \\
\hline $0-12$ years & 17 & 50 & 4 & 71 & $7 \%$ \\
\hline $13-16$ years & 222 & 246 & 79 & 547 & $50 \%$ \\
\hline 17 and Over & 172 & 143 & 162 & 477 & $43 \%$ \\
\hline \multicolumn{6}{|l|}{ Age b/ } \\
\hline $15-20$ years & 22 & 70 & 0 & 92 & $9 \%$ \\
\hline $21-25$ years & 222 & 141 & 0 & 363 & $34 \%$ \\
\hline $26-30$ years & 62 & 103 & 12 & 177 & $16 \%$ \\
\hline $31-35$ years & 47 & 36 & 22 & 105 & $10 \%$ \\
\hline 36 and Over & 58 & 89 & 188 & 335 & $31 \%$ \\
\hline \multicolumn{6}{|l|}{ Religion c/ } \\
\hline Agnostic or Atheist & 318 & 157 & 19 & 494 & $46 \%$ \\
\hline Buddhists, Taoists/ & 39 & 252 & 2 & 293 & $27 \%$ \\
\hline \multicolumn{6}{|l|}{ Confucian } \\
\hline Christian or Catholic & 18 & 23 & 178 & 219 & $21 \%$ \\
\hline Others & 36 & 7 & 25 & 68 & $6 \%$ \\
\hline Total effective & 411 & 439 & 245 & 1095 & $100 \%$ \\
\hline
\end{tabular}

a/ There were 20 no responses for gender in the U.S.

b/ There were 23 no responses for work experience and age in the U.S.

c/ There were 21 no responses for religion and nationality in the U.S.

$d /$ There were 23 no responses for national heritage in the U.S. 
Table 3

Independent Samples F-Test for Equality of Means, Chinese vs. Taiwanese vs. Americans

Respondents, Equal Variances not Assumed

\begin{tabular}{|c|c|c|c|c|c|c|c|c|}
\hline & \multirow[b]{2}{*}{ Questions } & \multicolumn{2}{|l|}{ China } & \multicolumn{2}{|c|}{ Taiwan } & \multicolumn{3}{|l|}{ U.S. } \\
\hline & & Mean & S.D. & Mean & S.D & Mean & S.D. & Sig. \\
\hline A 1 & Social Justice and Professional Ethics & 5.64 & 1.42 & 4.99 & 1.48 & 6.08 & 1.19 & $.000 * *$ \\
\hline 2 & General Sense of Morality & 5.73 & 1.43 & 5.19 & 1.45 & 6.14 & 1.22 & $.000 * *$ \\
\hline 3 & Monetary Award or Promotion & 3.09 & 1.98 & 3.5 & 1.8 & 2.71 & 1.72 & $.000 * *$ \\
\hline 4 & Policy of Organization on Whistle Blowing & 4.64 & 1.76 & 4.42 & 1.59 & 5.40 & 1.49 & $.000 * *$ \\
\hline 5 & Peer Encouragement & 3.76 & 1.9 & 3.92 & 1.64 & 3.94 & 1.82 & 0.285 \\
\hline 6 & Job Protection & 3.74 & 2.03 & 3.79 & 1.68 & 4.26 & 1.83 & $.000 * *$ \\
\hline B 1 & Strong Internal Control & 3.7 & 1.98 & 4.19 & 1.76 & 2.90 & 1.75 & $.000 * *$ \\
\hline 2 & Strong Legal System & 3.87 & 2.05 & 4.24 & 1.8 & 3.20 & 1.98 & $.000 * *$ \\
\hline 3 & Media Attention & 4.41 & 1.98 & 4.67 & 1.81 & 4.11 & .01 & $0.002 * *$ \\
\hline 4 & Retaliation from Organization & 4.66 & 1.91 & 4.51 & 1.78 & 3.70 & 2.00 & $.000 * *$ \\
\hline 5 & Retaliation from Involved Individuals & 4.77 & 1.87 & 4.72 & 1.83 & 3.36 & 1.97 & $.000 * *$ \\
\hline 6 & Own Religion & 2.61 & 1.81 & 2.35 & 1.35 & 1.36 & 0.76 & $.000 * *$ \\
\hline 7 & Own Moral Consciousness & 2.73 & 1.86 & 2.67 & 1.51 & 1.50 & 0.90 & $.000 * *$ \\
\hline 8 & Confucius Teaching & 2.86 & 1.78 & 2.9 & 1.46 & 1.74 & 1.05 & $.000 * *$ \\
\hline $\mathrm{C}_{1}$ & $\begin{array}{l}\text { Greater Monetary Amount in Fraud, Greater } \\
\text { Intention to Whistle Blowing }\end{array}$ & $\mathrm{r}_{4.74}$ & 1.84 & 4.46 & 1.67 & 4.36 & 2.07 & $0.026^{*}$ \\
\hline 2 & $\begin{array}{l}\text { Greater Impact of the Fraud, Greater } \\
\text { Intention to Whistle Blowing }\end{array}$ & r 5.99 & 1.41 & 5.52 & 1.36 & 5.25 & 2.11 & $.000 * *$ \\
\hline D 1 & $\begin{array}{l}\text { Personal Relationships Negatively Affecting } \\
\text { Intention for Whistle Blowing }\end{array}$ & & 1.69 & 4.72 & 1.45 & 3.38 & 1.78 & $.000 * *$ \\
\hline
\end{tabular}

$\mathrm{N}=1095 . \quad * * *$ Significant at the .05 and .01 levels, respectively. 
Table 4

Independent Samples t-Test for Equality of Means, Taiwanese vs. Chinese

Respondents, Equal Variances not Assumed

\begin{tabular}{|c|c|c|c|c|c|c|}
\hline & \multirow[b]{2}{*}{ Questions } & \multicolumn{2}{|c|}{ Taiwan } & \multirow{2}{*}{$\frac{\text { China }}{\text { Mean }}$} & \multirow[b]{2}{*}{ S.D. } & \multirow[b]{2}{*}{ Sig. } \\
\hline & & Mean & S.D. & & & \\
\hline A.1 & Social Justice and Professional Ethics & 4.99 & 1.48 & 5.64 & 1.42 & $.000 * *$ \\
\hline 2 & General Sense of Morality & 5.19 & 1.45 & 5.73 & 1.43 & $.000 * *$ \\
\hline 3 & Monetary Award or Promotion & 3.50 & 1.80 & 3.09 & 1.98 & $.002 * *$ \\
\hline 4 & Policy of Organization on Whistle Blowing & 4.42 & 1.59 & 4.64 & 1.76 & .061 \\
\hline 5 & Peer Encouragement & 3.92 & 1.64 & 3.76 & 1.90 & .207 \\
\hline 6 & Job Protection & 3.79 & 1.68 & 3.74 & 2.03 & 694 \\
\hline B.1 & Strong Internal Control & 4.19 & 1.76 & 3.70 & 1.98 & $.000 * *$ \\
\hline 2 & Strong Legal System & 4.24 & 1.80 & 3.87 & 2.05 & $.005^{* *}$ \\
\hline 3 & Media Attention & 4.67 & 1.81 & 4.41 & 1.98 & .052 \\
\hline 4 & Retaliation from Organization & 4.51 & 1.78 & 4.66 & 1.91 & .255 \\
\hline 5 & Retaliation from Involved Individuals & 4.72 & 1.83 & 4.77 & 1.87 & .741 \\
\hline 6 & Own Religion & 2.35 & 1.35 & 2.61 & 1.81 & $.019 *$ \\
\hline 7 & Own Moral Consciousness & 2.67 & 1.51 & 2.73 & 1.86 & .577 \\
\hline 8 & Confucius Teaching & 2.90 & 1.46 & 2.86 & 1.78 & .731 \\
\hline C. 1 & $\begin{array}{l}\text { Greater Monetary Amount in Fraud, Greater } \\
\text { Intention to Whistle Blowing }\end{array}$ & 4.46 & 1.67 & 4.74 & 1.84 & $.019 *$ \\
\hline 2 & $\begin{array}{l}\text { Greater Impact of the Fraud, Greater Intention to } \\
\text { Whistle Blowing }\end{array}$ & 5.52 & 1.36 & 5.99 & 1.41 & $.000 * *$ \\
\hline D. 1 & $\begin{array}{l}\text { Personal Relationships Negatively Affecting } \\
\text { Intention for Whistle Blowing }\end{array}$ & 4.72 & 1.45 & 4.87 & 1.69 & .177 \\
\hline
\end{tabular}

$\mathrm{N}=850 . \quad *, * *$ Significant at the .05 and .01 levels, respectively. 
Table 5

Independent Samples t-Test for Equality of Means, U.S. vs. Taiwanese

Respondents, Equal Variances not Assumed

\begin{tabular}{|c|c|c|c|c|c|c|}
\hline & \multirow[b]{2}{*}{ Questions } & \multicolumn{2}{|l|}{ U.S. } & \multicolumn{3}{|c|}{ Taiwan } \\
\hline & & Mean & S.D. & Mean & S.D. & Sig. \\
\hline A.1 & Social Justice and Professional Ethics & 6.08 & 1.19 & 4.99 & 1.48 & $.000 * *$ \\
\hline 2 & General Sense of Morality & 6.14 & 1.22 & 5.19 & 1.45 & $.000 * *$ \\
\hline 3 & Monetary Award or Promotion & 2.71 & 1.72 & 3.50 & 1.80 & $.000 * *$ \\
\hline 4 & Policy of Organization on Whistle Blowing & 5.40 & 1.49 & 4.42 & 1.59 & $.000 * *$ \\
\hline 5 & Peer Encouragement & 3.94 & 1.82 & 3.92 & 1.64 & .869 \\
\hline 6 & Job Protection & 4.26 & 1.83 & 3.79 & 1.68 & $.001 * *$ \\
\hline B. 1 & Strong Internal Control & 2.90 & 1.75 & 4.19 & 1.76 & $.000 * *$ \\
\hline 2 & Strong Legal System & 3.20 & 1.98 & 4.24 & 1.80 & $.000 * *$ \\
\hline 3 & Media Attention & 4.11 & 2.01 & 4.67 & 1.81 & $.003 * *$ \\
\hline 4 & Retaliation from Organization & 3.70 & 2.00 & 4.51 & 1.78 & $.000 * *$ \\
\hline 5 & Retaliation from Involved Individuals & 3.36 & 1.97 & 4.72 & 1.83 & $.000 * *$ \\
\hline 6 & Own Religion & 1.36 & 0.76 & 2.35 & 1.35 & $.000 * *$ \\
\hline 7 & Own Moral Consciousness & 1.50 & 0.90 & 2.67 & 1.51 & $.000 * *$ \\
\hline 8 & Confucius Teaching & 1.74 & 1.05 & 2.90 & 1.46 & $.000 * *$ \\
\hline C. 1 & $\begin{array}{l}\text { Greater Monetary Amount in Fraud, Greater } \\
\text { Intention to Whistle Blowing }\end{array}$ & 4.36 & 2.07 & 4.46 & 1.67 & .523 \\
\hline 2 & $\begin{array}{l}\text { Greater Impact of the Fraud, Greater Intention to } \\
\text { Whistle Blowing }\end{array}$ & 5.25 & 2.11 & 5.52 & 1.36 & $.074 *$ \\
\hline D. 1 & $\begin{array}{l}\text { Personal Relationships Negatively Affecting } \\
\text { Intention for Whistle Blowing }\end{array}$ & 3.38 & 1.78 & 4.72 & 1.50 & $.000 * *$ \\
\hline
\end{tabular}

$\mathrm{N}=684$. * ** Significant at the .05 and .01 levels, respectively. 
Table 6

Independent Samples t-Test for Equality of Means, U.S. vs. Chinese

Respondents, Equal Variances not Assumed

\begin{tabular}{|c|c|c|c|c|c|c|}
\hline & \multirow[b]{2}{*}{ Questions } & \multicolumn{2}{|l|}{ U.S. } & \multirow{2}{*}{$\frac{\text { China }}{\text { Mean }}$} & \multirow[b]{2}{*}{ S.D. } & \multirow[b]{2}{*}{ Sig. } \\
\hline & & Mean & S.D. & & & \\
\hline A. 1 & Social Justice and Professional Ethics & 6.08 & 1.19 & 5.74 & 1.42 & $.001 * *$ \\
\hline 2 & General Sense of Morality & 6.14 & 1.22 & 5.63 & 1.43 & $.000 * *$ \\
\hline 3 & Monetary Award or Promotion & 2.71 & 1.72 & 3.09 & 1.98 & $.010 * *$ \\
\hline 4 & Policy of Organization on Whistle Blowing & 5.40 & 1.49 & 4.64 & 1.76 & $.000 * *$ \\
\hline 5 & Peer Encouragement & 3.94 & 1.82 & 3.76 & 1.90 & .236 \\
\hline 6 & Job Protection & 4.26 & 1.83 & 3.74 & 2.03 & $.001 * *$ \\
\hline B.1 & Strong Internal Control & 2.90 & 1.75 & 3.70 & 1.98 & $.000 * *$ \\
\hline 2 & Strong Legal System & 3.20 & 1.98 & 3.87 & 2.05 & $.000 * *$ \\
\hline 3 & Media Attention & 4.11 & 2.01 & 4.41 & 1.98 & .064 \\
\hline 4 & Retaliation from Organization & 3.70 & 2.00 & 4.66 & 1.91 & $.000 * *$ \\
\hline 5 & Retaliation from Involved Individuals & 3.36 & 1.97 & 4.77 & 1.87 & $.000 * *$ \\
\hline 6 & Own Religion & 1.36 & 0.76 & 2.61 & 1.81 & $.000 * *$ \\
\hline 7 & Own Moral Consciousness & 1.50 & 0.90 & 2.73 & 1.86 & $.000 * *$ \\
\hline 8 & Confucius Teaching & 1.74 & 1.05 & 2.86 & 1.78 & $.000 * *$ \\
\hline C. 1 & $\begin{array}{l}\text { Greater Monetary Amount in Fraud, Greater } \\
\text { Intention to Whistle Blowing }\end{array}$ & 4.36 & 2.07 & 4.74 & 1.84 & $.018^{*}$ \\
\hline 2 & $\begin{array}{l}\text { Greater Impact of the Fraud, Greater Intention to } \\
\text { Whistle Blowing }\end{array}$ & 5.25 & 2.11 & 5.99 & 1.41 & $.000 * *$ \\
\hline D. 1 & $\begin{array}{l}\text { Personal Relationships Negatively Affecting } \\
\text { Intention for Whistle Blowing }\end{array}$ & 3.38 & 1.78 & 4.87 & 1.69 & $.000^{* * *}$ \\
\hline
\end{tabular}

$\mathrm{N}=656 . \quad *, * *$ Significant at the .05 and .01 levels, respectively.

\section{Copyright Disclaimer}

Copyright reserved by the author(s).

This article is an open-access article distributed under the terms and conditions of the Creative Commons Attribution license (http://creativecommons.org/licenses/by/3.0/). 